\title{
Social and Economic Problems of Makeover of the Village in the Republic of Sakha (Yakutia)
}

\author{
Egor Grigorievich Egorov ${ }^{1}$
}

\section{Mikhail Mihailovich Nikiforov²}

\author{
${ }^{1}$ Academy of Sciences of the Republic of Sakha (Yakutia) \\ 2 Information Analytical Center "Expert" Research Institute of Regional Economy of the North North-Eastern Federal University \\ Named After MK Ammosov; Correspondence: Mikhail Mihailovich Nikiforov, Yakutsk, Russian Federation
}

\author{
Doi:10.5901/mjss.2015.v6n5s4p365
}

\begin{abstract}
The article defines the particularities, social and economic problems of rural areas and the results of the agrarian reform in the Republic of Sakha (Yakutia). Special consideration is focused by the authors on the necessity of sociocultural rearrangement of the north rural areas. Their development is significantly affected by the extremal natural and climatic conditions of the far north and also commercial transformations of social and economic relations. In terms of history, the experience and results of separation of cattle houses from living yurts in the 1930s are summarized. One of the most important social and economic problems appeared in the process of commercial agrarian reform is the preferential development of individual gardens and farms (home) and peasant agriculture. Their livestock houses and other household outbuildings are generally disposed on the smallholdings of the rural sector that means the farm and cow yards are combined. As a result, socio-cultural contexts and sanitary bioenvironmental conditions of people's life in such villages essentially went downhill. That is why for makeover of rural areas, it is for the first time suggested by the authors as high priority measures to separate the cow yard from the living area. It is the essential factor of creation of the close-together arrangement of rural-type settlements and major contraction of extension of electricity mains, water lines, and other service lines, ultimately, retrenchment of material inputs and financial expenses for the fundamental rearrangement of Yakut rural areas. The organization of a cooperative cow yard with a cattle house and other constructions three-five kilometers away from the rural-type settlement is recommended for that purpose. The phased implementation of this very important social and economic action requires the development and adoption of a state-run program with principal federal, national, and municipal financing.
\end{abstract}

Keywords: socioeconomic problems, agrarian reform, separation of cattle houses from yurts and the cow yard from the living area

\section{Introduction}

The Republic of Sakha (Yakutia) is the hugest industrial and agrarian region of the Far North of the Russian Federation. The production sector, represented mainly by mining industries is the basis of the Republic's economy. Along with that, the agriculture has framework value and vital value because it serves as economic basis of traditional life activity of indigenous groups: the Sakha, Evenks, Evens, Yukaghir and other. 346.9 thousand people live in rural areas that equals to $35.4 \%$ from the overall population of the Republic.

\section{Literature Review}

The socioeconomic problems of agrarian transformations in Yakutia have been duly analyzed in the historical perspective. Herewith, some specific issues of the economic development of the rural areas of Yakutia in the northern conditions have been underexplored. For example, they include the separation of cow yards from yurts in the 1930s, on which there are only political and executive decisions, while the experience of it implementation has not been covered in scientific terms. And the issue of the cow yard separation from the living area emerged as a result of the agrarian reform in the period of the transition to market economy in the 1990s. It was raised firstly by the article authors in 2003 and was considered in few publications. Besides, popular science articles in this matter were published in republican mass media (Vinokurova, 2005). It should be noted that on the examined specific issues of makeover of the Yakut rural area, there have not yet been any researches by other authors. 


\section{Research Methodology}

Archival documents for research of the historical experience of agrarian transformations in Yakutia, in particular the separation of cattle houses from yurts in the 1930s, were used. Particularities and results of agrarian transformations in the Republic of Sakha (Yakutia) were analyzed on the basis of statistical information and in-house study during scientific research expeditions. An essential problem in modern conditions of sociocultural transformation of the village is the separation of cow yard from living area in rural-type settlements. The problems were first set up and studied by the authors by way of concrete inspection of rural-type settlements and also on the basis of questionnaire survey of villagers.

\subsection{Separation of Cow Yards from Yurts in Yakutia}

Prosperous families of farmers and particularly rich kulak farmsteads in Yakutia kept animals in separate facilities (big cattle houses), which were placed considerably far from the residential house and yard. They usually employed cattlemen and other workers for fatigue duties. The live-stock handling in the cattle house attached to the yurt was typical for poor rural families, which composed the main part of rural population. It is possible to understand that it was a necessary method of farm management in conditions of severe winter and minuscule financial standing of rural population.

The cattle management in the cattle house attached to the yurt let poor farmers save materials and efforts for the construction, the house owners - milk cows and see after them without getting out of humid cattle house to the yard in cold winter months. But such method of cattle management created hard unhygienic conditions in the living area. Through the neighboring door, the odor of fresh manure and manure pump leaked, but also the bellow of animal stock disturbed the repose of inhabitants throughout the day and night. As a result public health suffered acutely, they were usually sick with tuberculosis and other public health hazards. Scientists wrote about it at the beginning of the XX century: "Overcrowded accommodation of people lived in yurts, ammonia evaporation in cattle houses combined with the living areas, the dry fug of the land floor area, the dirt of fur (coat), public wipers, the darkness of yurts, the absence of sequestration-all this created significant opportunities for incidence of ophthalmic diseases, and especially trachoma" (Sakhastat, 2001).

The processes of reforming the backward traditional forms of economic management in agriculture and radical revolutionary reconstruction of the entire lifestyle of nations of the Russian North, including the nations of Sakha, began since the first days of establishment of Soviet power in Yakutia. In particular, an adopted regulation of the $3^{d}$ session of the General Executive Committee of Yakutia of $2^{\mathrm{d}}$ convocation was of great importance. It took place from March 28 to the April 1, 1924 where together with the rest of important economic affairs, the social issues were considered too, such as abolition of illiteracy of adult population and separation of cattle houses from yurts. Later in the year, on May 7, the voluntary society "Yraas oloh" ("Clean household") was established for implementation of mass agitation work among population with the purpose of preventive measures and eradication of infectious diseases, for separation of cattle houses from yurts. This society was liquidated in April 1925 as having completed its functions. Of course, it was impossible to separate cattle houses from yurts just in one year on the huge territory of Yakutia. Not without reason, on January 5, 1926, the decision "About separation of yurts from cattle houses" (Kalashnikov, 2004), of the Office of Regional Committee of the All-Union Communist Party of Bolsheviks of Yakutia was adopted, which accelerated this process to some extent.

In 1924-1927, sampling observations of the population were held to inspect the tuberculosis incidence by the terms of living. Among the examined 67,009 farmsteads, $22 \%$ had separated cattle houses, $78 \%$ did not have separated cattle houses. Out of the general number of farmsteads, 28,080 farmsteads belonged to poor peasants (41.9\%), 21,220 (31.7\%) - to poor-and-middle-peasants, 2,600 (3.9\%)-to prosperous peasants. Therefore, on August 1, 1927, the decision "About interdiction of new construction of residential houses united with cattle houses (cattle barn)" of the CEC of Yakutia was adopted. Persons offending this Decision were subject to administrative enforcement-compulsory labors under article 192 of the Criminal Code of RSFSR for a period of one month or a fine up to 100 rubles. In 1928, the Soviet Government allocated 25,000 rubles to organize separation of cattle houses. This work besides the health authorities also engaged the People's Commissariat for Agriculture. Since the middle of 1930s, socialist competitions between regions for separation of cattle houses, construction of block houses, and amelioration of the sanitary and epidemiological state of populated localities began. Thus, the total separation of dwelling with ground floor from attached stock rooms and the beginning of construction of blockhouses was the revolutionary socio-economic transformation of the traditional lifestyle of the Sakha. Under the conditions of organization of communal farms (kolkhozes) in the early 1960s and the existence of state farms (sovkhozes) until the beginning of 1990s, cattle generally was socialized and was kept in cattle houses placed in specially arranged territories within or next to settlements. 


\subsection{The Agrarian Reform in the Transition to Market Relations}

\subsubsection{Transformation of Business Forms in Animal Breeding}

Since the early 1990s, both across Russia, and particularly in Yakutia, the transition to market relations was effected. The agrarian reform specifically was getting through in rural areas. The rural population of the Republic had a small number of individual cattle and horses (Table 1) and keeping cattle in yards and in cattle houses next to living areas did not have any significant negative effect on the ecology of rural areas.

Table 1. Cattle stock and horses owned by the population the Republic of Sakha (Yakutia) (as of the beginning of the year)

\begin{tabular}{lcccccc}
\hline Figures & 1936 & 1951 & 1961 & 1991 & 2006 & 2013 \\
\hline Cattle, thousands of animals & 381.2 & 88.4 & 92.0 & 115.8 & 155.1 & 112.1 \\
Share in the total stock (cattle stock), \% & 85.8 & 27.7 & 25.9 & 28.3 & 57.8 & 52.1 \\
Horses, thousands of animals & 114.4 & 2.1 & 1.4 & 31.6 & $47.0^{\star *}$ & 47.6 \\
Share in the total stock of horses, \% & 64.7 & 1.3 & 0.9 & 15.8 & 35.9 & 28.0 \\
Pigs, thousands of animals & 7.4 & 4.2 & 19.0 & 58.6 & 16.6 & 6.6 \\
Share in the total stock of pigs, \% & 64.9 & 57.5 & 44.1 & 52.8 & 43.9 & 24.3 \\
Rural population, thousands of people & 310.2 & $225.5^{\star}$ & $254.8^{\star}$ & 372.6 & $343.6^{\star \star *}$ & 335.1 \\
\hline Animals per capita on the average & & & & & & \\
\hline Cattle stock & 1.23 & 0.39 & 0.36 & 0.31 & 0.45 & 0.33 \\
Horses & 0.37 & 0.009 & 0.005 & 0.085 & 0.14 & 0.14 \\
Pigs & 0.024 & 0.019 & 0.075 & 0.16 & 0.04 & 0.02 \\
\hline
\end{tabular}

One of their principle directions were denationalization and privatization of state agricultural enterprises of the Republic of Sakha (Yakutia), including sovkhozes. As a result different forms of patterns of ownership and economic management appeared, including private, represented by personal subsidiary plots of the population and peasant farms (Table 2).

Table 2. Dynamics and structure of changes in cattle stock by the economic forms in the Republic of Sakha (Yakutia) (as of January 1 , in thousands of animals)

\begin{tabular}{lccccccc}
\hline Figures & 1991 year & 1993 year & 2000 year & 2004 year 2006 year 2011 year 2013 year \\
\hline Stock (black cattle) in all categories of households & 409.2 & 423.9 & 284.5 & 301.4 & 268.1 & 233.9 & 215.1 \\
Increase to 1991year, \% & 100.0 & 103.6 & 69.5 & 73.6 & 65.5 & 57.2 & 52.6 \\
Including: & & & & & & & \\
In personal subsidiary plots of the population & 115.8 & 159.2 & 186.2 & 210.4 & 155.1 & 120.1 & 112.1 \\
Share of total, \% & 28.3 & 37.6 & 65.5 & 69.8 & 37.9 & 23.3 & 27.4 \\
In farms and kinship communities & - & 27.8 & 43.0 & 50.5 & 76.6 & 66.9 & 57.2 \\
Share of total, \% & - & 6.6 & 15.1 & 16.8 & - & - & - \\
In agricultural enterprises & 280.2 & 226.2 & 51.6 & 37.1 & 33.5 & 43.8 & 42.9 \\
Share of total, \% & 68.5 & 53.3 & 18.1 & 12.3 & 8.2 & 10.7 & 10.5 \\
In homesteading of enterprises & 13.2 & 10.7 & 3.7 & 3.3 & 2.9 & 3.0 & 2.9 \\
Share of total, \% & 3.2 & 2.5 & 1.3 & 1.1 & 0.7 & 0.7 & 0.7 \\
\hline
\end{tabular}

As seen from Table 2, in the course of the years of commercial transformations, general cattle stock considerably reduced, but a variety of types of ownership and economic management appeared. After liquidation of sovkhozes in the Republic, the relative density of state agricultural enterprises to 2013 reduced to $10.5 \%$. While before 2004 , the personal subsidiary plots of the population prevailed, the share of which as of January 1, 1991 increased from $28.3 \%$ to $69.8 \%$, due to the organization of farms their share for the last 10 years decreased by the beginning of 2013 to $27.4 \%$.

\subsubsection{Performance Indicators of Manufacturing Products by Branches and Forms of Ownership}

The output of a branch in households of the population and peasant farms in 2013 exceeded the output of agricultural enterprises 3 times (Table 3). 
Table 3. Indicators of agricultural output by category of farms the Republic of Sakha (Yakutia) (in effective prices, million rubles)

\begin{tabular}{lcccccc}
\hline & 2000 & 20005 & 2010 & 2011 & 2012 & 2013 \\
\hline $\begin{array}{l}\text { 1. Agricultural enterprises, homesteading-total: } \\
\text { including: }\end{array}$ & 1074.8 & 2408.8 & 4836.2 & 4866.6 & 4818.4 & 5319.0 \\
crop farming & & & & & & \\
breeding & 329.9 & 603.0 & 776.7 & 852.7 & 980.5 & 1048.6 \\
\hline $\begin{array}{l}\text { 2. Farms of the population-total: } \\
\text { including: }\end{array}$ & 744.8 & 1805.8 & 4059.5 & 4013.9 & 3837.9 & 4270.4 \\
$\begin{array}{l}\text { crop farming } \\
\text { Breeding }\end{array}$ & 3735.5 & 7051.2 & 8495.3 & 8978.3 & 9880.7 & 10242.7 \\
\hline $\begin{array}{l}\text { 3. Peasant (private) farms-total: } \\
\text { including: }\end{array}$ & 1074.0 & 2095.5 & 3447.1 & 3639.2 & 4157.2 & 4460.6 \\
crop farming & 2661.5 & 4955.6 & 5047.2 & 5339.1 & 5723.5 & 5782.0 \\
breeding & 630.9 & 2740.3 & 4552.1 & 4994.9 & 5001.2 & 5305.7 \\
\hline & 204.7 & 532.0 & 883.8 & 857.2 & 1080.1 & 1299.5 \\
& 426.2 & 2208.3 & 3668.3 & 4137.7 & 3921.0 & 4006.2 \\
\hline
\end{tabular}

The structural features of the agricultural products output by categories of households is provided in Table 4.

Table 4. Production profile of agricultural production the Republic of Sakha (Yakutia) by category of farm units (in historical prices in $\%$ from farm units of all categories)

\begin{tabular}{lcccccc}
\hline & 2000 & 2005 & 2010 & 2011 & 2012 & 2013 \\
\hline $\begin{array}{l}\text { 1. Agricultural enterprises, } \\
\text { homesteading-total: }\end{array}$ & 19.8 & 19.7 & 27.0 & 25.8 & 24.5 & 25.5 \\
$\begin{array}{l}\text { including: } \\
\text { crop farming } \\
\text { breeding }\end{array}$ & 20.5 & 18.5 & 15.2 & 16.0 & 15.8 & 15.4 \\
\hline $\begin{array}{l}\text { 2. Farms of population-total: } \\
\text { including: }\end{array}$ & 19.4 & 20.1 & 31.8 & 29.7 & 28.5 & 30.4 \\
$\begin{array}{l}\text { crop farming } \\
\text { breeding }\end{array}$ & 68.7 & 57.8 & 47.5 & 47.7 & 50.1 & 49.1 \\
\hline $\begin{array}{l}\text { 3. Peasant (private) farm-total: } \\
\text { including: }\end{array}$ & 66.8 & 64.9 & 67.5 & 68.0 & 66.8 & 65.5 \\
crop farming & 69.4 & 55.2 & 39.5 & 39.6 & 42.4 & 41.1 \\
breeding & 11.6 & 22.5 & 25.5 & 26.5 & 25.4 & 25.4 \\
\hline & 12.7 & 16.5 & 17.3 & 16.0 & 17.4 & 19.1 \\
& 11.1 & 24.6 & 28.7 & 30.7 & 29.1 & 28.5 \\
\hline
\end{tabular}

For last 14 years, due to the progressive transformation of private subsidiary farming in peasant (private) farms, the share of their agricultural products reduced from $68.7 \%$ to $49.1 \%$. And the share of peasant (private) farms increased from $11.6 \%$ to $25.4 \%$ ).

The agrarian reform in particular at the early stage caused a commercial crisis: decline in agricultural production, growth of unemployment, sharp decrease of profit of rural families, decline in their subsistence support due to the markettype commodity circulation. In such recessionary conditions, the priority development of personal subsidiary plots allowed the major part of the rural population of the Republic to ensure self-employment, self-provisioning with staples-meet, milk, and butter, and, ultimately, survival through self-organization.

Herewith, personal small-holdings and peasant farms mostly are natural, that means semi-subsistence ones. As a result these forms of agricultural productivity cannot provide the desired level of cash income of the rural population and the development of the market sector of the agricultural economy (Table 5).

Table 5. Venality of agricultural productivity in the Republic of Sakha (Yakutia)

\begin{tabular}{|c|c|c|c|c|c|c|}
\hline Type of production & 1991 & 1995 & 2000 & 2005 & 2010 & 2013 \\
\hline \multicolumn{7}{|c|}{ sold in $\%$ of the volume of production in population's households } \\
\hline Potatoes & 4.3 & 6.1 & 18.6 & 25.0 & 18.6 & 21.4 \\
\hline Vegetables & 1.6 & 5.2 & 12.3 & 27.7 & 12.3 & 23.5 \\
\hline Meat (live weight basis) & 19.4 & 17.6 & 24.5 & 36.3 & 50.4 & 51.4 \\
\hline Milk & 4.1 & 2.8 & 30.2 & 63.6 & 30.2 & 48.4 \\
\hline
\end{tabular}




\begin{tabular}{lcccccc}
\hline \multicolumn{7}{l}{ sold in \% of the volume of production in peasant farms } \\
\hline Potatoes & - & 25.3 & 64.1 & 60.2 & 56.8 & 41.7 \\
Vegetables & - & 63.6 & 58.4 & 60.1 & 51.4 & 51.4 \\
Meat (live weight basis) & - & 45.2 & 96.0 & 41.4 & 54.3 & 59.5 \\
Milk & - & 37.9 & 88.8 & 55.4 & 71.7 & 70.3 \\
\hline
\end{tabular}

\subsection{Separation of Cow Yard from Living Area}

The essential feature of stock-rearing in personal subsidiary plots and peasant farms is organization of a cow yard next to the house on small farmlands. Its territory is defined by regulatory documents as $0.30 \mathrm{Ha}$. On farmlands of rural families, the living area and the cow yard are usually located, as well as a garden for growing potatoes and vegetables.

The buildings on a cow yard are a cattle house, a loft barn, a fence for graziery and also in some cases a hog house and a stable. They occupy considerable area, which on the average equal up to $50 \%$ of farmlands of rural families. That means up to $30 \%$ of the general area of rural-type settlements. On every cow yard, there are 2 to 20 cattle, 1 to 2 horses, and, in winter, also colts and female horses. As can be seen from the above, in a rural-type settlement, cattle and horses exceed the number of permanently residing people.

Such organization of a cow yard becomes a natural part of the traditional lifestyle of the rural population of the Republic. It is conditioned not only by the severe natural climatic conditions and practicability of close placement of the cattle house to the living area for convenience of routine maintenance of cattle in winter months. And also by necessity of protection of private property. Cows milking, feeding, and cattle management begin every day at 6-00 AM and finish between 6-00 and 7-00 PM. In winter, mass cow calving begins. During this period, it is necessary to organize twentyfour-hour alert of all family members. All these painstaking jobs are carried out in the old-fashioned way, without any automation. Unfortunately, nowadays, cases of moonlighting from cattle houses and velour grasses from the yard have become more frequent.

\section{Results}

Thus, the family work in a personal subsidiary plot is rather difficult and exhausting, but very important for economical self-provisioning. It is important for those families who do not have or are limited in other sources of income. In the rural areas, the latter categories reach $25-30 \%$ on the average.

At the same time, to timely discuss and search the solutions, it is better to raise the question about the problems of further development of personal subsidiary plots, as well as peasant farms, taking into account the necessity of removal of their main disadvantages in the sociocultural life. They include:

- Primitive procedures, manual feeding, milking, barn and slush cleaning, and other types of work that require low-end and exhausting physical labor.

- The low level of zootechnical, veterinary, and breeding work, poor quality of milk and meat, incomplete utilization of hides and wastes.

- Non-abidance by the procedures of labor safety and social security of workers of personal subsidiary plots, which is followed by non-payment of temporary incapacity allowances, pensions and insurance contributions, non-registration of work records, non-provision of holidays and vacations, the lack of free time for professional and cultural development of people engaged in the personal subsidiary plots.

The necessity of placement of a cow yard on the farmlands of rural families creates unsanitary conditions for the population and environmentally unfriendly conditions for communities. Besides, the placement of multiple cow yards taking up to $30 \%$ of the overall territory of communities significantly increases expenses and causes big difficulties for municipal improvement, construction of local power lines, streets, gas pipe lines, water pipelines, and other utility lines.

The first three of the listed disadvantages of personal subsidiary plots of the population do not require any special proofs. Therefore, we will try to explain only the practicability and possibility of full or partial elimination of the last disadvantage.

\section{Discussing}

Full elimination assumes separation of the cow yard from the living area and its placement outside the community. It would be the best choice for the municipal improvement, providing normal sanitary and ecological conditions for the community. Also, it would substantially reduce the expenses for the construction of power lines, gas pipe lines, water 
pipes, and other pipelines and networks. However, currently, such socioeconomic innovative measure will not be supported by the major part of the rural population, because it means liquidation of personal subsidiary plots and a new agrarian crisis.

This is evidenced to by results of a survey of the rural population in 19 settlements, eight uluses of the Republic, which was held in January-February 2004 by the Institute of Regional Economics of the Academy of Sciences of the Republic of Sakha (Yakutia) with participation of the Institute of Human Investigations of the Academy of Sciences of the Republic of Sakha (Yakutia) and students of the Finance and Economics Institute of the Yakut State University. The analysis showed that $43 \%$ of respondents agreed with moving cattle houses, piggeries, chicken farms and other facilities outside the living area of villages for its sanitary and hygienic and ecological improvement. This proposition was mainly supported by the population of the following uluses: Vilyuysky-44.7\%, Megino-Kangalassky $-45.7 \%$, Ust'-Aldansky$49 \%$, Churapchinsky $-50.7 \%$. As for the separation of cow yards from living areas by building collective (cooperative) standard cattle houses outside settlements, $47.8 \%$ replied positively, $44.7 \%$-negatively, $7.5 \%$ were not determined. To acquire more valid opinion of the rural population on such important social questions, it is necessary to, first, preliminarily raise awareness; second, to provide wider coverage, at least 5\% of the population (Nikiforov \& Okhlopkov, 2004).

In modern circumstances, a more real choice is restricting the size of cow yards and making stricter the health requirements to its maintenance through incorporation of annexes to the law "About personal subsidiary plots of citizens in the Republic of Sakha (Yakutia)" dated June 14, 2000 No. 207-II and the Law the Republic of Sakha (Yakutia) "About introduction of amendments and additions in the Law the Republic of Sakha (Yakutia) "About personal subsidiary plots of citizens in the Republic of Sakha (Yakutia)", " approved by Decree of the President the Republic of Sakha (Yakutia) dated December 10, 2004 No. 1863 in the form of the following approximate provisions:

- On the cow yard of a rural family, it is allowed to keep up to 5 cattle. According to the standard design, a cattle house without dung matting must be constructed. It is prohibited to fatten cattle throughout the year on the territory of settlements. The practice of shepherd is recommended.

- The households, which have more than 5 cattle, must be given convenient plots outside settlements for organization of cow yards. Also, it is desirable according to the standard designs to build cooperative mechanical cattle houses for 25-100 cattle stalls. For the creation of such cooperatives, the government grants subventions and credits for the period of 3-5 years. Milkmaids and cattlemen can be employed. Herewith, "sayylychny" type of cattle management (traditional form) became more real in summer.

The implementation of cow yard separation from the living area should be started with building cooperative cattle houses outside settlements. For that, subventions and credits in the amount of 100 million rubles out of 312 million rubles additionally allocated for the accumulative development fund of rural areas should be provided.

According to the above, it is understood that the separation of cow yards from the living area is an urgent social and economic problem of rural areas. Its solution requires fundamental changes in the methods of organization of personal subsidiary plots and peasant farms, definition of ways and measures of their development in the system of various forms of ownership and economic management in rural areas. With account of the complexity and contradiction of socioeconomic transformations and fundamental realignment of rural areas with the purpose of creation of its newlook, it is suggested at the current stage to carry out economic, social, and legal research.

\section{Conclusions}

In the course of implementation of the agrarian reform in the early 1990s with the purpose of establishing market relations, different forms of ownership and economic management developed in agribusiness. In rural areas, radical socioeconomic transformations took place. Their results appeared contradictory, i.e. both positive, and negative. But generally, the transition to the market economy can be considered progressive.

Further development of the agrarian reform requires achieving qualitative improvement of socioeconomic transformations, improving the economic efficiency of agricultural sectors and the strong competitive position of products. With account of the severe climate, the specific socio-geographic and demographic conditions of the Republic, it is necessary to implement comprehensive modernization of the social and economic development of rural areas based on usage of Russian and foreign innovative scientific achievements, technology and practice.

We can note that its first step is implementation of the Republican Program of socioeconomic development of rural areas in the Republic of Sakha (Yakutia) in three periods: 2002-2006, 2007-2011 and 2012-2017. At the following stage of modernization of rural areas, principally new purposes and goals are set. For example, leveling off the social development of rural and urban territories, removing the large gap in the standards of living of rural and urban population, achieving radical reorganization of rural areas. In our opinion, in the long view, such problem, specific for our Yakut rural 
areas, must be decided as separation of cow yards from living areas, taking into account the historical experience of the 1920s-1930s regarding separation of cattle houses from yurts. That is why, the need in further study of the raised issues remains. But it requires a public contract of the Government of the Republic of Sakha (Yakutia).

\section{References}

Egorov, E. G., Nikiforov, M. M., Vinokurova, D. M., \& Zhegusov, Yu. I. (2005). Analytic scientific note on the topic of "New-look of Yakutsk village in XXI century" following the results of questionnaire survey, which was directed in Ministry of Agriculture of the Republic of Sakha Yakutia by the letter (p. 55).

Kalashnikov, A. A. (2004). Yakutia. Chronicle, Facts, Events: 1917-1953 (pp.63-80). Committee of state archival work affiliated to the government the Republic of Sakha (Yakutia). National Archives the Republic of Sakha (Yakutia). Yakutsk: Bichik.

Program of socioeconomic development of rural areas of the Republic of Sakha (Yakutia) for 2002-2006.

Program of socioeconomic development of rural areas of the Republic of Sakha (Yakutia) for 2007-2011.

Program of socioeconomic development of rural areas of the Republic of Sakha (Yakutia) for 2012-2017.

Statistical Yearbook of the Republic of Sakha (Yakutia). (2004). Statsbornik (p. 488). Yakutsk: Sakhapoligrafizdat.

Statistical Yearbook of the Republic of Sakha (Yakutia). (2012). Statsbornik (p. 79). Yakutsk: Sakhapoligrafizdat.

Statistical book. (2004). Agricultural activities of farms of the population the Republic of Sakha (Yakutia) (p. 53). Komgosstat of the Republic of Sakha (Yakutia). Yakutsk.

Statistical book. (2014). Agricultural activities of farms of the population the Republic of Sakha (Yakutia) (p. 58). Komgosstat of the Republic of Sakha (Yakutia). Yakutsk.

Statistical book. (2003). Core indicators of A.I.C. the Republic of Sakha (Yakutia) for 1997-2002 years (p. 86). Komgosstat the Republic of Sakha (Yakutia). Yakutsk.

Statistical book. (2014). Farm economy the Republic of Sakha (Yakutia) (p. 150). Yakutsk: Sakhastatizdat.

Official Publication of the State Committee of the Russian Federation for Statistics. (2001). Yakutia: XX century in the mirror of statistics (p.79). Yakutsk: Sakhapoligrafizdat. 